NBER WORKING PAPER SERIFS

GENERAL EQUILIBRIUM AND BUSINESS CYCLES

Fischer Black

Working Paper No. 950

NATIONAL BUREAU OF ECONOMIC RESEARCH 1050 Massachusetts Avenue

Cambridge MA 02138

August 1982

The research reported here is part of the NBER's research program in Fconomic Fluctuations. Any opinions expressed are those of the author and not those of the National Bureau of Economic Research. 


\title{
ABSTRACT
}

The general equilibrium models in this paper, with complete markets, can give the major features of business cycles. The models include real investment, but information is costless and is avallable to everyone at the same time. Fluctuations in the match between resources and wants across many sectors create major fluctuations in output and unemployment, because moving resources from one sector to another is costly. Fluctuations in the demand for the services of durable goods causes much larger fluctuations In the output of durables, and causes unemployment that takes the form of temporary layoffs. Since speclalized factors cooperate in producing goods and services, it makes sense to lay people off in groups rather than lowering wages and walting for them to quit. Simllarly, a vacancy is created when a spectalized factor is missing from such a group. Technology comes with varying levels of risk and expected return assoclated with the degree of specialization. More specialization means more severe fluctuations and a higher average level of unemployment, along with a higher average level of output and growth. Monetary policy, Interest rates, and fiscal policy have no special roles to play in the model.

\author{
Fischer Black \\ Professor of Finance \\ Massachusetts Institute of Technology \\ Sloan School of Management \\ 50 Memorial Drive \\ Cańbridge, MA 02139
}

(617) 253-6691 


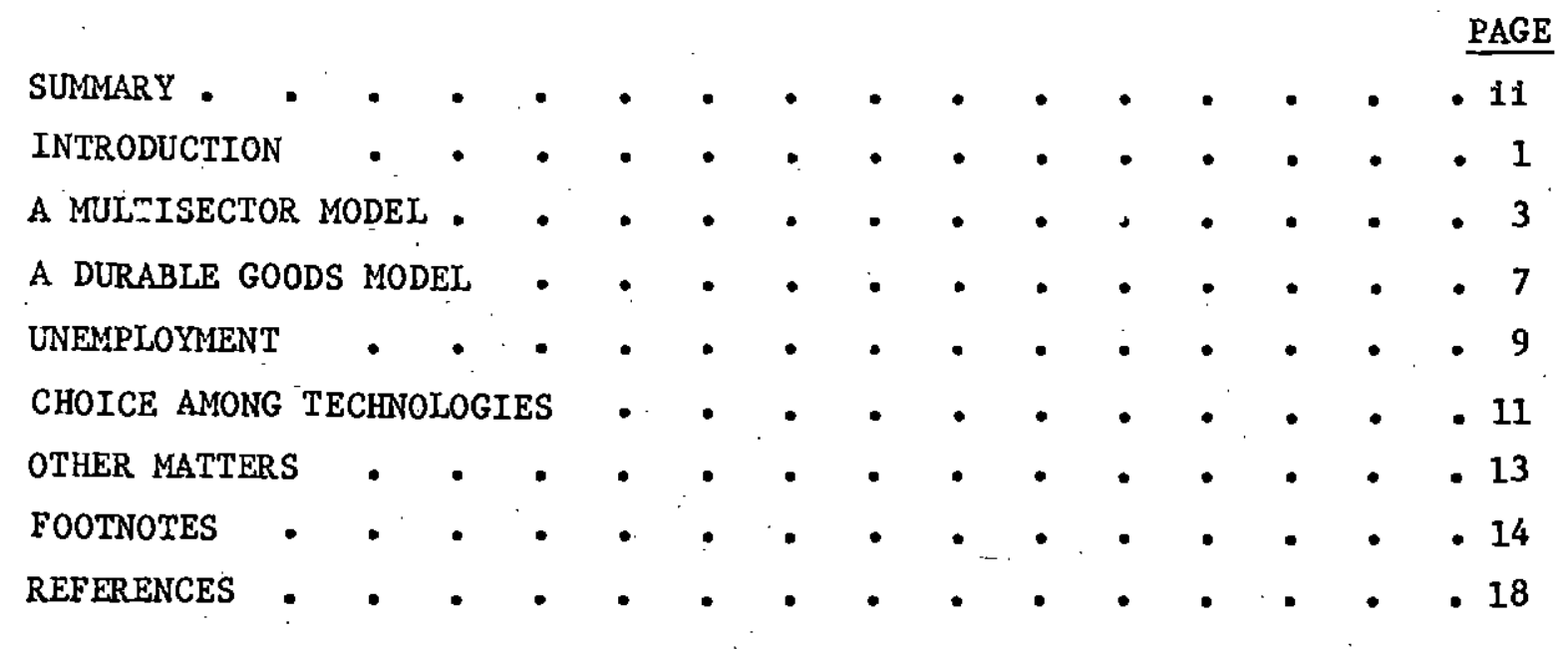




\section{GENERAL EQUILIBRIUM AND BUSINESS CYCLES *}

Fischer Black ${ }^{\dagger}$

INTRODUCTION

Business cycles are fluctuations in economlc activity. Most measures of economic activity look something like a random walk with drift: successive changes in the level of economic activity are largely independent. ${ }^{\circ}$ Changes in the level of economic activity in different sectors are quite highly correlated, but output of durables fluctuates more than output of nondurables. Output of durables and unemployment both show some tendency to return, over time, to normal levels. The normal levels of durables output and unemployment tend to change, so the path of any measure of economic activity can be quite complex. We will take unemployment as the variable that best captures the fluctuations we want to understand. ${ }^{1}$

General equilibrium models ${ }^{2}$ take individuals as maximizing the expected value of a utility function, where utility depends on consumption at various times of various goods and services, and on state variables that can be taken to represent tastes. 3 We will assume that markets are complete, so we can show that one does not need incomplete markets to understand the major features of business cycles: this means that the state variables representing tastes are observable, and are the basis for some of the traded securities. ${ }^{4}$ We will include physical investment: in fact, we will assume that a variety of technologies are available at any time. The available technologies also depend on state variables. Individuals bear costs in shifting their human capital from one sector to another, and in shifting physical capttal from one sector to another. These adjustment costs seem largely internal: I do not believe that significant externalities in this process have been clearly identified. 5

Thus the models in this paper are entirely consistent with maximizing behavior on the part of individuals and firms in light of the information they have and the opportunities they face. 6 It hardly makes sense, in my view, to work 
with models that do not assume maximizing behavior. At the same time, there is no easy way to test these models or to estimate the constants in a mode1.7 The models I discuss are very incomplete, and it is always very difficult to use observations of economic data to help us understand the economy. Since we do not know the true model, correlation implies almost nothing about causation. 
A MULTISECTOR MODEL

It is possible to model business cycles using a model with a single good and a single composite production sector. ${ }^{8}$ Fluctuations in economic activity in a model like this appear as fluctuations in the stock of capital. 9 Such a model, however, does not lend itself to an analysis of unemployment. To have unemployment in a model with maximizing behavior, we need a multisector mode1, 10

Both human and physical capital will be specialized, because specialization increases expected productivity. However, there are shocks to both tastes and technology in the form of unexpected shifts in the state variables in the economy. As a result, we find ourselves with a capital stock whose composition is different from the composition we would have chosen had we known in advance what the world would be like. The match between resources and wants is not perfect.

We will want to shift capital from the sectors where we have too much to the sectors where we have too little. Relative prices will motivate this shift. But the less advance notice we have, the more costly it is to shift capital between sectors. ${ }^{11}$ Also, the more different the sectors are from one another, the more costly it is to shift capital from one to the other.

Shocks that create a poor match, which will mean large shifts of human capital between sectors, cause unemployment and a decline in output. Shocks that create a good match will bring unemployment below its average level and output above its average level. As resources are shifted between sectors, the match will improve. The shocks combined with the shift of resources will cause unemployment to wander around its average level: when it is near its average leve1, its movements will be largely random; but when it is far from Its average level, the random movements will be combined with a drift back toward its average level. of course, the average level will also be changing through time as tastes and technology change.

Shifting resources between sectors is just one source of unemployment. Other sources will have somewhat different behavior. Also, a shift of resources can. 
occur without unemployment. Job changes can occur without an intervening perlod of search or walting for a new job. This model suggests, though, that job turnover associated with a change from one employer to another will be higher in bad times than in good times.

The more sectors there are, the more ways there are for the match to go wrong. A model that has only consumption goods and investment goods will not be able to generate much unemployment through this device. A model with a single good will not produce any of this kind of unemployment at all.

Similarly, no one source of uncertainty, such as uncertainty about relative prices associated with price level uncertainty, will generate much unemployment in this model. It is the large number of partly independent shoska to different sectors that genarates signiflcaut unemployment.

Unemployment generated this way will show considerable persistence, because it costs less to move resources between sectors slowly than to move them quickly. A mismatch between resources and wants will be corrected at a rate that balances the benefits of a better match against the costs of a faster movement of resources.

The government can reduce the unemployment rate by subsidizing decilning sectors and taxing rising sectors, or by ordering the goods and services produced in the declining sectors. This will improve welfare only if one person's unemployment imposes unavoldable costs on others. The case for the existence of this kind of externality has not been made, in my view. ${ }^{12}$

To make this model more concrete, let's use a simple example with just two sectors. Imagine that all individuals are identical, and the world lasts for only one period. At the start of the period, an individual chooses amounts $x$ and $y$ of resources 1 and 2 from a constant elasticity of transformation production frontier: ${ }^{13}$

$$
1=\left(x^{b} / c+y^{b} / d\right)^{1 / b}
$$


The Individual chooses $x$ and $y$ knowing that his utility function will be Cobb-Douglas, of the form

$$
u=x^{a} y^{2-a}
$$

but without knowing the exact value of a .

At the end of the period, the individual learns the value of $a$, and has a chance to transform $x$ into $y$ or $y$ into $x$. The terms on which the transformation can be made take the form of another constant elasticity of transformation production frontier that is tangent to the first frontier at tine poinc $x, y$. The second frontler is inside the first fronster because last-minute changes are more costly than changes made in advance.

$$
1=\left(x^{b^{*}} / c^{*}+y^{b^{*}} / d^{*}\right)^{1 / b^{*}}
$$$$
\begin{aligned}
& b^{*}>b \\
& c^{*}>0 \\
& d^{*}>0
\end{aligned}
$$

The final amounts chosen, $x^{*}$ and $y^{*}$, are determined by the point at which the new production frontier (3) is tangent to the indifference curves (2). It turns out that this point can be derived analytically with no trouble. First, the values of $b^{*}, c^{*}$, and $d^{*}$ are determined by:

$$
1=x^{b *} / c^{*}+y^{b *} / d^{*}
$$

$$
x^{b *} / c^{*}=x^{b} / c
$$

Then the values of $\dot{x}^{*}$ and $y^{*}$ are determined by: 
(7)

$$
x^{*} b^{*} / c^{*}=a
$$

(8)

$$
y^{*} b^{*} / d^{*}=1-a
$$

A perfect match occurs when $x^{*}$ is equal to $x$ and $y^{*}$ is equal to $y$ - In that case, it would not have helped to know a in advance. That represents the maximum possible utility for the individual. The worse the match, the lower the individual's utility will be. 
A DURABLE GOODS MODEL

In addition to the process involving a match between resources and wants across sectors, there is a process operating within any sector that produces durable goods. This process helps explain both temporary layoffs and the exact form that the business cycle takes. 14

Suppose that demand falls for the services of durable goods produced by a given sector. Since the stock of durable goods deteriorates slowly, output of these goods will fall sharply until the stock of goods comes more into line with demand, given the cost of producing new goods. The decline in output will be associated with a fall in the relative price of these goods. ${ }^{15}$

As the stock of ducailes comes into line, output wili gracually risa, unless changed by a new shock to tastes or technology. Thus durables will introduce a pattern of a sharp fall in output followed by a gradual rise, or a sharp rise in output followed by a gradual fall. These patterns will be added to a pattern of random changes due to new shocks, so they will not be seen in pure form.

Output of durables will respond more to new information than output of nondurables. Thus sectors producing durables should show larger cyclical fluctuations than sectors producing nondurables.

Moreover, some of the changes in output in a durable goods sector will be temporary. A temporary decline in output will be associated with temporary layoffs. Thus the behavior of durable goods helps us understand another component of unemployment. ${ }^{16}$

Again, let's make the discussion more concrete by working out a simple example. Assume that the loss of utility from having the wrong stock of durables is proportional to the square of the difference between the actual stock $x$ and the target stock $k$, and has welght $g^{2}$. Assume that the loss of utility associated with adjusting the stock of durables is proportional to the square of the rate of adjustment $\dot{x}$. Assume that we can ignore discounting. Finally, assume that output $y$ is for replacement of 
depreciated capital at rate $q x$ plus adjustment of the stock of capital at rate $\dot{\mathbf{x}}$.

Assume all individuals are identical, and want to minimize the total loss of utility over an infinite lifetime associated with a shock that moves $k$ away from the initial value $x^{*}$ of the stock $x$ of durables.

(9)

$$
\text { Minimize: } \int_{0}^{\infty}\left[g^{2}(x-k)^{2}+\dot{x}^{2}\right] d t
$$

The Individual chooses a path for $\dot{x}$ that minimizes the value of this integral. Using the calculus of variations, we find that the solution is:

$$
x-k=\left(x^{*}-k\right) e^{-g t}
$$

$$
\dot{x}=-g\left(x^{*}-k\right) e^{-g t}
$$

$$
y=q x-g\left(x^{*}-k\right) e^{-g t}
$$

We can see that a sudden change in $k$ will cause a sudden change in $y$, followed by a gradual change in $y$ in the opposite direction. 
UNEMPLOYMENT

Unemployment, in the models outlined above, takes two forms. One form is assoclated with costly shifts of human capital between sectors when there is a poor match between resources and wants. The other is assoclated with temporary layoffs when times are bad in durable goods sectors. These two kinds of unemployment will tend to rise and fall together, though they will not always be perfectly in phase. Output will tend to fall when unemployment rises, and to rise when unemployment falls. Unemployment will be countercyclical; or if we use unemployment to define the business cycle, we can say that output is procyclical. ${ }^{17}$

So far, the models have nothing to say about why firms fire or lay off their employees in bad times rather than lowering wages so that the desired number w111 quit. Some of the reasons are obvious. An employee who quits will not generally be eligible for unemployment benefits under current law, so the employee and employer may agree to make it an involuntary termination. An employee who has been notifled through a wage reduction that it's time to think about leaving may not be very productive: he may even do things that harm his employer.

More generally, though, I think the reason 1 ies in the fact that production involves the cooperation of a number of people with specialized skilis. A firm cares about more than just the number of employees. When a few key employees leave, the others may become much less productive. Thus it is natural to close down a whole unit at once, and to lay off or transfer essentially all the employees of that unit.

The cooperative production notion may also help us understand vacancies. When a key person has left a unit that is being kept open, or when a key person is missing from a unit being reopened, it can be important to find that person quickly. A firm will use advertising or hiring bonuses to do it. It will not use high wages for that person unless a person with the desired ski11s will receive high wages anywhere he works.

Can the models outlined above help us understand why workers with less 
seniority are generally laid off first, or why young people have a relatively high unemployment rate? I think so. Young people have more time to recoup the costs of changing sectors, so they will favor an arrangement that gives them higher pay than they would otherwise get in exchange for the risk of being laid off first in a downturn. A worker with less seniority has fewer skills specific to the job, so a relatively small decline in the sector the worker is in will make other jobs more attractive.

These models do imply that in a downturn, the rate at which workers move from one sector to another will rise. This may be hard to see at first, since people who are laid off may not know yet whether they will be changing sectors or not. The number of quits may fall in a downturn, because of a reduction in the number of vacancies (as defined above) and because people who would otherwise quit may now be laid off. This will be especially true in sectors producing durable goods.

Since we are assuming that markets are complete, long term contracts do not play any special role. ${ }^{18}$ It is not restrictive to have long term contracts available along with shorter term contracts. 
CHOICE AMONG TECHNOLOGIES

In the models outlined above, we discussed the choice among technologies only in very general terms. An individual could choose a point along a production frontier that put resources into each of two sectors. Sectors, however, can be defined in many ways. A more specialized worker and a less specialized worker can be taken as being in different sectors, even though they participate in production processes with the same outputs.

Specialization is associated with both risk and productivity. When certain factors affecting tastes and technology are uncertain, there is a risk that a specialized factor will not be wanted. On the other hand, if it is wanted, the productivity of a specialized factor will generally be higher than the productivity of a nouspecialized facter doing the sane job. In other words, greater specialization means that when the match between resources and wants is good, output will be very high, but when the match is bad, output will be very low. It is very costly to move a specialized factor from one kind of task to another.

Note that the risks in the use of specialized resources do not cancel. High demand in one sector does not offset low demand in another, since it is costly to shift resources from the low demand sector to the high demand sector. When the match is poor, output will be low and unemployment will be high.

Individuals will choose investments in human and physical capital that reflect their preferences. The more tolerant of risk they are, and the more tolerant of unemployment they are, the more specialized the chosen resources will be. Higher risk and higher unemployment will be associated with higher expected output and growth.

Note that if markets are incomplete, people will be less able to exchange risks, so they will choose less specialization, less severe business cycles, lower output, and lower growth. Similarly, if people have less information, a given degree of specialization will be riskier, so they will cut back both risk and expected productivity. 
Note also that the magnitude of fluctuations in output and unemployment tells us very little about welfare. Since large fluctuations are associated with rapid growth, there is no index of welfare that takes into account only the magnitude of fluctuations. The government can dampen fluctuations by taxing risk or by taxing specialization in any of several ways, but this seems more likely to reduce welfare than to increase it, because it introduces unnecessary distortions. 
OTHER MATTERS

In a model with complete markets, inflation will play no role at a11. In the real world, inflation is associated with certain costs, such as the cost of changing prices, the cost of contracting in real terms, and the cost of economizing on the use of currency. With one exception, these costs seem small compared to the cost of a mismatch between resources and wants.

The exception is that when inflation turns to large deflation and the nomina 1 riskless short term interest rate falls to zero, we have a "currency trap." The real interest rate is forced to be higher than it would be in the absence of currency. This can cause major dislocations, and $I$ believe it was one reason for the severity of the great depression.

I believe that monetary policy is not a cause of variations in the rate of inflation. ${ }^{19}$ Even if it does influence inflation, though, it will not have s significant influence on business cycles under the models outlined above.

Similarly, fiscal policy can affect the business cycle in ways discussed above. The government can subsidize declining sectors or buy their output. It can tax specialization or risk-taking. It will thereby reduce the magnitude of fluctuations and the average level of unemployment, but will probably reduce welfare at the same time because it will distort investment choice. Similarly it can subsidize unemployment by paying generous unemployment benefits. 20 Assuming that these activities are 11mited, fiscal policy will not play a significant role either increasing or decreasing the magnitude of business cycles. 


\section{FOOTNOTES}

* I am grateful for comments on earlier drafts by many people, including those who don't agree with me. A less formal description of this model appears in Black (1981).

† Sloan School of Management, Massachusetts Institute of Technology.

- Nelson and Plosser (1981) discuss the random walk nature of macroeconomic time series.

1 This characterization of business cycles is close to Arrow's (1978, p. 160). For more extensive characterizatiors of business cycles that are consistent with general equilibrium models, see Lucas (1977, p. 9), Kydland and Prescott (1978, pp. 1-2), and Hodrick and Prescott (1981).

2 For analyses of genberal equilibrium models, see Arrow (1971), Debreu (1959), and Hirshleifer (1970).

3 The utility functions used in general equilibrium models are often assumed to be state-independent. For example, Diamond (1967) uses a state-independent utility function. He notes (p. 761, n. 6) that this is a restrictive assumption. Hirshleifer (1970, p. 220) uses a "uniqueness" axiom to rule out state dependent utility functions. Phelps (1962, 1967, p. 141) uses a utility function that is independent of both time and state. On the other hand, Fama (1970) and Feiger (1976) use models with state-dependent utility functions. The original von Neumann-Morgenstern (1953) axioms ensure the existence of utility functions defined over both states and consumption streams, but Marshak (1950, p. 113) eliminates the state dependence in his version of the existence theorem. Lucas (1977, pp. 20, 25) includes changing tastes as part of his theory of business cycles. Krelle (1973, esp. pp. 105-106 and pp. 115-116) discusses several ways in which tastes change, involving the influence of past consumption of a good on its present and future utility. Vickrey (1964, pp. 23-24) describes, without bringing them into his later theories, various kinds of 
changes in tastes that may be important in the behavior of an economy. He mentions in particular the conscious development of tastes, either by the individual himself or by others.

4 The use of state-dependent utility functions does not 1mply that taste changes are being used as a catch-all explanation for anything that cannot otherwise be explained since tastes are taken to be observable. I will assume that the utility function itself is constant: at that level, tastes are constant too. Stigler (1966, p. 39) argues that it is best to treat tastes as fixed at a lower level: that it is best to use a state-dependent utility function, in effect. Stigler and Becker (1977, p. 76) say: "The establishment of the proposition that one may usefully treat tastes as stable over time and similar among people is the central task of this essay." But ir. the examples they give, it is more the highest level utility function that is constant. They redefine commodities in a way that effectively indexes then by the state of the world. The use of state-indexed commodities as arguments in the utility function is equivalent to the use of a state dependent utility function. Pollack (1978, p. 375) notes that Stigler and Becker should be objecting to the use of unobservables, whether of tastes or technology, rather than to the use of taste differences and taste change.

5 The use of adjustment costs in production functions has been formalized by Lucas (1967), Uzawa (1969), and Jorgenson (1972). The Idea that there are adjustment costs in shifting labor from one sector to another has been developed by Herberg (1972). This model has been extended to allow for finite adjustment costs for both labor and capital by Herberg and Kemp (1972).

6 Lucas (1975, pp. 1113-1114) gives a compelling argument for using models based on maximizing behavior. The trouble with models containing disequilibrium or arbitrary elements is that they are as unstable as the economy itself is. The arbitrary elements surely change, but the ways in which they change are not specified in the model. And it is usually true that if all economic agents come to have a full understanding of a disequilibrium model, the model will no longer describe the world 
correctly. Models based on the work of Keynes $(1936,1965)$ have such disequilibrium elements as an interest rate that differs from the marginal product of capital, or a wage that is not free to move. Models based on the work of Lucas (1975) depend on easily cured ignorance about the current state of the world and on inability to create simple securities.

7 The difficulties with the use of econometrics in trying to discover the structure of the economy are discussed by Black (1982), Pratt and Schlaifer (1982), and Leamer (1982).

8 Merton's (1973) intertemporal capital pricing model can be used as a model of business cycles, though he doesn't suggest such a use.

9 Kydland and Prescott (1978, pp. 3-4) argue plausibly that we can characterize the elements responsible for the persistence of business cycles as "capital-like elements." Their discussion ( .11$)$ of business cycles has at least two other features in common with the model in this paper: the notion that taste changes are important, and the notion that the effects of certain kinds of shocks cannot be diversified away.

${ }^{10}$ Lucas and Prescott (1974, p. 190) set up a multisector model of unemployment with stochastic demand in each market. They impose constraints on the model that keep it from being a model of business cycles. Hayek (1939) includes as part of his theory the notion that specialization of labor in the presence of uncertainty is one cause of fluctuations in employment. Kydland (1980) has a real business cycle model in which costs of adjustment between sectors are important.

${ }^{11}$ Alchian (1959) discusses the relation between production cost and such factors as the amount of time available for planning the production run.

12 Diamond (1981) discusses some possible external effects of this kind.

$1{ }^{3}$ Powe 11 and Gruen (1968) discuss this kind of production frontier.

${ }^{14}$ The role played by intermediate goods in Long and Plosser (1982) is 
similar to the role played in this mode1 by durable goods. Kydland and Prescott's (1981) "time to build" also involves the effects of durable goods. Sargent (1979, pp. 160-170) has an equilibrium theory of layoffs in which "sticky" wages play a role.

15 This kind of argument is standard in accelerator models. For a traditional discussion of the accelerator in business cycle theory, see Hicks (1946, esp. 299-302). Lucas (1977, p. 23) has a more modern description. Durable goods also play an important role in Kydland and Prescott's (1980) "competitive theory of fluctuations."

${ }^{16}$ In particular, it is not necessary to assume non-separable utility. Barro and King (1982) discuss the differences between models with separable and non-separable uti11ty. Durable goods play an important role in their models, too.

${ }^{17}$ In Long and Plosser (1982), unemployment will tend to $r$ ise when output rises if producers switch inputs more easily than consumers switch between consumption of the commodity and consumption of leisure.

${ }^{18}$ For models in which long term contracts do play a special role, see Burdett and Mortensen (1980).

${ }^{19}$ For an introduction to my views on monetary policy, see Black (1972). For an alternate view of monetary policy in a real business cycle model, see King and Plosser (1982).

${ }^{20}$ Benjamin and Kochin (1979, p. 474) state: "We have shown that the persistently high rate of unemployment in interwar Britain was due in large part not to deficient aggregate demand but to high unemployment benefits relative to wages." 
REFERENCES

Alchian, Armen. "Costs and Outputs." in Moses Abramovitz et. al., The Allocation of Economic Resources. (Stanford: Stanford University Press, 1959), pp. 23-40.

Arrow, Kenneth J. Essays in the Theory of Risk-Bearing. Chicago: Markham, 1971.

Arrow, Kenneth, J. "The Future and the Present in Economic Life." Economic Inquiry 16 (April, 1978): 157-169.

Barro, Robert J., and Robert G. King. "Time-Separable Preferences and Intertemporal-Substitution Models of Business Cycles." NBER Working Paper No. 888 (May, 1982).

Black, Fischer. "Acti Je and Passive Monetary Policy in a Neoclassical Mode1." Journal of Finance 27 (September, 1972): 801-814. Black, Fischer. "The ABCs of Business Cycles." Financial Analysts Journal 37 (November/December, 1981): 75-80.

Black, Fischer. "The Trouble with Econometric Models." Financial Analysts Journal 38 (March/April, 1982): 29-37.

Burdett, Kenneth, and Dale.T. Mortensen. "Search, Layoffs, and Labor Market Equilibrium." Journal of Political Economy 88 (August, 1980): 652-672.

Debreu, Gerard. Theory of Value: An Axiomatic Analysis of Economic Equilibrium. New York: Wiley, 1959.

Diamond, Peter A. "The Role of a Stock Market in a General Equilibrlum Model with Technological Uncertainty." American Economic Review 62 (September, 1967): 759-778.

Diamond, Peter. "Externalities and Efficiency in a Model of Stochastic Job Matching." Unpublished memorandum (November, 1981).

Fama, Eugene. "Multiperiod Consumption - Investment Decisions." American Economic Review 60 (March, 1970): 163-174.

Feiger, George. "What is Speculation?" Quarterly Journal of Economics 90 (November, 1976): 677-687.

Hayek, Friedrich A. von. Profits, Interest, and Investment, and Other Essays on the Theory of Industrial Fluctuations. London: Routledge \& K. Paul, 1939 . 
Herberg, Horst. "On a Two-Sector Growth Model with Non-Shiftable Capital and Labour-Market Imperfections." Zeitschrift fur die Gesamte Staatswissenschaft 128 (Apri1, 1972): 10-21.

Herberg, Horst, and Murray C. Kemp. "Growth and Factor Market

'Imperfections." Zeitschrift fur die Gesante Staatswissenschaft 128 (November, 1972): 590-604.

Hicks, John R. Value and Capital (second edition). 0xford: Clarendon Press, 1946.

Hirshleifer, Jack. Investment, Interest, and Capital. Englewood Cliffs, New Jersey: Prentice-Hal1, 1970.

Hodrick, Robert J., and Edward C. Prescott. "Post-War U.S. Business Cycles: an Empirical Investigation." Unpublished memorandum (May, 1981).

Jorgenson, Dale W. "Investment Behavior and the Production Function." Bell Journal of Economic and Management Science 3 (Spring, 1972): 220-251.

Keynes, John Maynard. The General Theory of Employment, Interest, and Money. New York: Harcourt, Brace, 1936. First Harbinger Edition, 1965. King, Robert G., and Charles I. Plosser. "The Behavior of Money, Credit and Prices in a Real Business Cycle." NBER Working Paper No. 853 (February, 1982).

Kre1le, W. "Dynamics of the Utility Function." in J.R. Hicks and W. Weber, eds. Carl Menger and the Austrian School of Economics. (London: Oxford University Press, 1973), pp. 92-128.

Kydland, Finn. "Analysis and Policy in Competitive Models of Business Fluctuation." Unpublished memorandum (May, 1980).

Kydland, Finn, and Edward C. Prescott. "Persistence of Unemployment in Equilibrium." Unpublished memorandum (Apri1, 1978).

Kydland, Finn E., and Edward C. Prescott. "A Competitive Theory of Fluctuations and the Feasibility and Desirability of Stabilization Policy." in Stanley Fischer, ed. Rational Expectations and Economic Policy (Chicago: University of Chicago Press, 1980), pp. 169-198.

Kydland, Finn E., and Edward C. Prescott. "Time to Build and Aggregate Fluctuations." Unpublished memorandum (September, 1981).

Leamer, Edward E. "Let's Take the Con Out of Econometrics." Unpublished memorandum (January, 1982). 
Long, John B., Jr. and Charles I. Plosser. "Real Business Cycles."

Unpublished memorandum (February, 1982).

Lucas, Robert E., Jr. "Adjustment Costs and the Theory of Supply." Journal of Political Economy 75 (August, 1967): 321-335.

Lucas, Robert E., Jr. "An Equilibrium Model of the Business Cycle." Journal of Political Economy 83 (December, 1975): 1113-1144.

Lucas, Robert E., Jr. "Understanding Business Cycles." in Karl Brunner and

Allan H. Meltzer, eds. Stabilization of the Domestic and

International Economy (Volume 5 of the Carnegie-Rochester

Conference series on Public Policy. Amsterdam: North-Holland, 1977), pp. 7-29.

Lucas, Robert E., Jr. and Edward C. Prescott. "Equilibrium Search and Unemployment." Journal of Economic Theory 7 (February, 1974): 188-209.

Marshak, Jacob. "Rational Behavior, Uncertain Prospects, and Measurable

Utility." Econometrica 18 (April, 1950): 111-141.

Merton, Robert C. "An Intertemporal Capital Asset Pricing Model."

Econometrica 41 (September, 1973): 867-887.

Nelson, Charles R., and Charles I. Plosser. "Trends and Random Walks in

Macroeconomic Time Series: Some Evidence and Implications."

Unpublished memorandum (December, 1981).

von Neumann, John and Oskar Morgenstern. Theory of Games and Economic

Behavior (third edition). Princeton: Princeton University Press, 1975.

Phelps, Edmund S. "The Accumulation of Risky Capital: A Sequential Utility Analysis." Econometrica 30 (October, 1962): 729-743. Reprinted in Donald Hester and James Tobin, eds. Risk Aversion and Portfolio Choice (New York: Wiley, 1967), pp. 139-153.

Pollack, Robert. "Endogenous Tastes in Demand and Welfare Analysis." American Economic Review 68 (May, 1978): 374-379.

Powe11, Alan A., and F.H.G. Gruen. "The Constant Elasticity of Transformation Production Frontier and Linear Supply System." International

Economic Review 9 (October, 1968): 315-328.

Pratt, John W., and Robert Schlaifer. "On the Nature and Discovery of

Structure." Unpublished memorandum (March, 1982).

Sargent, Thomas, J. Macroeconomic Theory. New York: Academic Press, 1979. 
Stigler, George J. The Theory of Price (third edition). New York: Macmillan, 1966.

Stigler, George J. and Gary S. Becker. "De Gustibus Non Est Disputandum." American Economic Review 67 (March, 1977): 76-90.

Uzawa, Hirofumi. "Time Preference and the Penrose Effect in a Two Class Model of Economic Growth." Journal of Political Economy 77 (July/August, 1969): 628 -652.

Vickrey, William S. Microstatics. New York: Harcourt, Brace \& World, 1964. 